\title{
鋼製部分球形殼の弾塑性座屈耐力に関する解析的研究 NUMERICAL STUDY OF ELASTIC-PLASTIC BUCKLING STRENGTH OF STEEL SPHERICAL CAPS
}

\author{
千葉義 尚*, 加藤 史郎** \\ Yoshinao CHIBA and Shiro KATO
}

\begin{abstract}
The main aim of this paper is to present several "elastic-plastic buckling strength" of uniformly pressurized perfect and imperfect steel spherical caps by using F.E.M. with updated Lagrangian Jaumann stress(corotational stress) rate formulation. Numerical examples include asymmetrically imperfect caps. Through parametric studies, the elastic-plastic buckling characteristics, especially stress distributions and yieldings are also illustrated. Numerical results are normalized and plotted against slenderness parameters. The knockdown factors are also examined by giving inward dimple type imperfections and asymmetric pieshaped imperfections. A comparison is made, in view of buckling stresses, with the values given by buckling strength curves in the codes and with past experimental and analytical results.
\end{abstract}

Keywords : sphericap cap, elastic-plastic buckling, updated Lagrangian Ahmad Shell element, co-rotaional stress, buckling strength curve 部分球形殼、弾塑性座屈、updated Lagrangian、Ahmad Shell 要素、共回転応力、座屈耐力曲線

\section{1. 序}

既往の研究： 薄肉款の座屈に関しては膨大な数の研究 成果が発表されている12)。円筒殼については弹塑性座 屈も含めてかなりの研究が蓄積され、設計規準としてま とめられている゙う。一方、球形款においては弾性座屈に 関しては実験的研究や非線形弾性座屈解析による研究が 蓄積され、設計規準 4 ()5)に取り入れられているものの、弾 塑性を考虑する必要があると思われる範囲では球形款の 実験データが非常に少なく、数值解析的な研究において も対象とする球形殼をいくつか取り上げて弾塑性座屈解 析を行った(例)-11)はあるが、広範囲の部分球形款を対 象にして系統的に応力性状や塑性化の進展状況、初期不 整の影響を調べた研究はきわめて少ない。薄肉款に関す る諸外国の規準・指針4)5)においては、その基本となる 実験データ及び経験式が異なるが、形状初期不整及び断 面の塑性化の影響を低減係数で評洒し、実験データの下 限值に適合させながら、座屈耐力曲線がシェルの細長比
の関数として示されている。

研究の目的：Galletly $5^{11)}$ は溶接による鋼製半球款の 実験結果（DTMB）を対象とし初期不整デー夕を整理 して、BOSOR5による弾塑性解析結果と比較して各種 の設計曲線を検証している。筆者らは既報12)13)において 軸対称・等分布荷重を受ける周辺固定の部分球形殻に対 して、回転殼要素による有限要素法を用い、弹性座屈に 限定して、線形座屈解析と非線形弹性座屈解析を広範囲 な細長比について実行し、座屈荷重の表現方法について 比較・考察を行ない、座屈応力度に基づく座屈耐力曲線 を求め、既往の研究結果及び設計曲線と比較した。その 際、等価膜応力度を用いて弾塑性域での座屈耐力推定の 可能性について検討したが、シェルの細長比がほぼ 1 . 0以下の範囲においては弾塑性座屈解析が必要であると の結論を得た。そこで今回は良く検証された、比較的精 度の高い弾塑性座屈解析プログラムを新たに作成し、弾 塑性座屈性状を調べることを目的とする。

\footnotetext{
* 法政大学工学部建築学科 助手・修士 (工学)

Research Assoc., Dept. of Architecture, College of Engineering, Hosei Univ., M. Eng.

** 豊橋技術科学大学建設工学系 教授 · 博士 (工学)

Prof., Dept. of Architecture and Regional Planning, Toyohashi Univ. of Technology, Dr. Eng.
} 
研究の方法: 既報 ${ }^{12)}$ の解析モデルに対して、共回転の 応力增分を使った updated Lagrangian型の有限要素法 を用い、弾塑性を考慮する必要があると思われる範囲の 細長比について弾塑性座屈解析を実行し、弾塑性座屈時 の応力性状・塑性化の進展状況について比較・考察を行 なう。また、形状初期不整を有する場合についても弾塑 性座屈解析を実行し、不整による座屈荷重の低減係数を 調べる。これらの結果より、座屈応力度に基づく座屈耐 力曲線を求め、既往の研究結果及び設計曲線と比較し、 弾塑性域での座屈而力推定について検討する。

\section{2. 有限要素法による解析手法及び解析条件}

\section{1 弾塑性座屈解析の基本仮定}

今回用いた有限要素法プログラムに関する主な仮定は 以下の通りである。

i) 大变形、大ひずみを伴う強非線形問題に対応できる、 Updated Lagrangian Jaumann stress rate (U.L.J.)

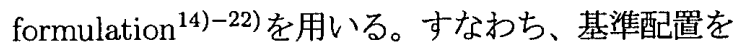
常に更新し、共回転の応力増分を用いる。

ii) 9節点Ahmad Shell 要素を使用する。積分点は $3 \times$ 3 のGauss積分とした注1)。ただし、軸対称変形の み考慮する場合は回転殼要素による幾何学的非線形 解析結果との比較注2)加ら、積分点は $2 \times 2$ の一 様低减積分とした。

iii）公称応力を用いて表された増分型の仮想仕事の原 理を、Kirchhoff応力の Jaumann微分を用いて変換 し、増分型の剛性方程式を定式化する。14)-16)

iv）各ステップで応力值の更新に際しては体積変化の項 を無視して、Cauchy 応力の Jaumann微分を Kirchhoff 応力の Jaumann 微分で近似する ${ }^{20) 。 ~}$

$$
[\Delta \sigma] \approx[\Delta t]=\left[\Delta t^{*}\right]-[\Delta \omega][\sigma]+[\sigma][\Delta \omega]
$$

ここに、 $\left[\Delta t^{*}\right]$ は Kirchhoff 応力の Jaumann 微分、 $[\sigma]$ はCauchy 応力、 $[\Delta \omega]$ はスピン・マトリクス、 $[\triangle \sigma]$ は Cauchy応力増分、 $[\Delta t]$ は Kirchhoff応力增 分である。

v）板厚方向については層分割法により層ごとに塑性 化を考虑し、積分はNewton-Cotes 型の 9 点積分 を用いる。ただし、弾性解析については 2 層とし、 Gauss - Legendre 型の 2 点積分を用いる。

vi）弾塑性構成式 ${ }^{23)}$ はMieses の降伏条件式、Levy Mises の流れ則、加工硬化則を用いる。材料は鋼 を想定し、等方硬化則を仮定する。

vii）荷重の変位依存性は考慮しない。

2. 2 有限要素法の基本式

ここで述べる定式化は既に論文等14)15)19)で発表されて いるものであるが、解法手順を明確にするためにChang
らの論文1516)を引用して記述しておく。 時刻 $t$ における配置 $\theta_{i}$ を基準として、公称応力 $\tilde{S_{i j}}$ を用い た仮想仕事の原理は次式のように表される。

$$
\begin{aligned}
& \int_{V_{\theta}}\left(\tilde{S_{i j}}+\triangle \tilde{S_{i j}}\right) \delta\left(\frac{\partial \Delta u_{j}}{\partial \theta_{i}}\right) d V= \\
& \int_{V_{\theta}}\left(\tilde{F}_{i}+\triangle \tilde{F}_{i}\right) \delta \triangle u_{i} d V+\int_{S_{\theta}}\left(\tilde{T}_{i}+\Delta \tilde{T}_{i}\right) \delta \triangle u_{i} d S
\end{aligned}
$$

ここに、 $\triangle \widetilde{S_{i j}}$ は時刻 $t$ における公称応力増分であり、 $\tilde{F}_{i}, \tilde{T}_{i}$ はそれぞれ物体力、表面力を表す。 updated Lagrangian 定式化を用いると、時刻 $t$ における配置（更新 された座標 $x_{i}$ ）を基準として、仮想仕事の原理は次式の ように表される。

$$
\begin{aligned}
& \int_{V_{t}}\left(\sigma_{i j}+\triangle \tilde{S_{i j}}\right) \delta\left(\frac{\partial \Delta u_{j}}{\partial x_{i}}\right) d V= \\
& \int_{V_{t}}\left(F_{i}+\triangle F_{i}\right) \delta \triangle u_{i} d V+\int_{S_{t}}\left(T_{i}+\triangle T_{i}\right) \delta \triangle u_{i} d S
\end{aligned}
$$

ここに、 $\sigma_{i j}$ は時刻 $t$ における Cauchy 応力増分であり、公 称応力増分 $\triangle \tilde{S}_{i j}$ は Kirchhoff 応力の Jaumann 微分 $\triangle S_{i j}^{*}$ を用いて次のように表される。

$$
\begin{aligned}
\Delta \tilde{S_{i j}} & =\Delta S_{i j}^{*}+\sigma_{i k} \frac{\partial \triangle u_{j}}{\partial x_{k}}-\left(\sigma_{i k} D_{j k}+\sigma_{j k} D_{i k}\right) \\
\triangle S_{i j}^{*} & =C_{i j k l} D_{k l} \\
D_{i j} & =\frac{1}{2}\left(\frac{\partial \triangle u_{i}}{\partial x_{j}}+\frac{\partial \triangle u_{j}}{\partial x_{i}}\right)
\end{aligned}
$$

式（4）をマトリクス表示すれば、

$$
[\triangle s]=\left[\Delta t^{*}\right]+[\sigma][\Delta e]-[\triangle \epsilon][\sigma]-[\sigma][\triangle \epsilon]
$$

ここに、 $[\triangle s]$ は公称応力増分、 $[\Delta e]$ は変位勾配マトリ クス、 $[\triangle \epsilon]$ はEulerのひずみ (速度) ${ }^{19)}$ である。尚、こ の式を用いることにより剛性マトリクスは対称となる。 式（4）を用いて式（3）を増分型に書き直すと、

$$
\begin{aligned}
\int_{V_{t}}\left[C_{i j k l} D_{k l} \delta D_{i j}\right. & \left.-\frac{1}{2} \sigma_{i j} \delta\left(2 D_{i k} D_{k j}-\frac{\partial \triangle u_{k}}{\partial x_{i}} \frac{\partial \triangle u_{k}}{\partial x_{j}}\right)\right] d V \\
& =R(t+\triangle t)-\int_{V_{t}} \sigma_{i j} \delta D_{i j} d V
\end{aligned}
$$

ここに、 $R(t+\Delta t)$ は式（3）の右辺である。 上式が U.L.J. を用いた増分型の仮想仕事の原理である。 Bathe らの定式化 ${ }^{14)}$ では Cauchy 応力の Jaumann微分が 用いられている。

\section{3 数值解析手法}

球形款に対して、Ahmad Shell 要素による有限要素 法14)を用いて、次式の増分形の釣合方程式及び剛性マ トリクス（線形岡性、幾何剛性）を誘導し、NewtonRaphson 法と修正 Riks - Wempner法24)を用いて幾何 学的非線形解析及び弹塑性座屈解析を行なった注2)。今 
回の解析においては軸対称変形のみを考慮した場合、周 方向に $10^{\circ}$ のモデルを想定し、要素分割は経線方向に 9 要 素 19 節点（自由度数 $57 \times 5=285$ ) とした。変位の軸対 称条件には多点拘束条件式 ${ }^{25)}$ (Multipoint Constraints) を採用した。また、非軸対称変形を含む場合は周方向に 1/2対称モデルを設定し、7 2 要素 323 節点（自由 度数 1615）とした。尚、今回の解析においては非軸対称 分岐座屈荷重は求めていない注3)。

$$
\begin{aligned}
& \left(\left[K_{L}\right]+\left[K_{N}\right]\right)\{\Delta u\}=\{\Delta P\} \\
& {\left[K_{L}\right]=\int_{V_{t}}\left[B_{L}\right]^{T}\left[D_{e p}\right]\left[B_{L}\right] d V} \\
& {\left[K_{N}\right]=\int_{V_{t}}\left(\left[B_{1}\right]^{T}[\sigma]\left[B_{1}\right]-2\left[B_{2}\right]^{T}[\sigma]\left[B_{2}\right]\right) d V} \\
& \{\triangle P\}=\{R(t+\Delta t)\}-\int_{V_{t}}\left[B_{L}\right]^{T}\{\sigma\} d V
\end{aligned}
$$

ここに $\left[D_{e p}\right]$ は弾塑性マトリクス、 $\left[B_{L}\right]$ は線形のひずみ マトリクス、 $\left[B_{1}\right] 、\left[B_{2}\right]$ はそれぞれ式 $(7)$ の左辺第 3 項、第 2 項に関連するひずみマトリクスである。

2.4 解析モデルの幾何形状、材料定数、境界条件、

荷重条件、形状初期不整

回転殼の幾何形状、変位、応力の定義を図 1 に示す。今 回解析を行ったモデルは既報の解析モデル12)を用いた。 解析条件は表 1 及び表 2 、設定した形状初期不整分布を 図2、3に示す。モデルの設定に用いた式は下記の通り である。

$$
\begin{aligned}
\bar{\lambda}_{s} & =\sqrt{\sigma_{y} / \sigma_{c l}} \\
& =\sqrt[4]{3\left(1-\nu^{2}\right)} \times \sqrt{\sigma_{y} / E} \times \sqrt{R / t} \\
\sigma_{c l} & =P_{c l} R / 2 t=E / \sqrt{3\left(1-\nu^{2}\right)} \cdot(t / R)
\end{aligned}
$$

軸対称初期不整 ${ }^{11)}$ 及び非軸対称初期不整分布 ${ }^{91}$

$$
\begin{aligned}
w_{i m p}(s)= & \left(w_{i m p}\right)_{\max }\left[1-\left(2 s / L_{c r}\right)^{2}\right]^{3} \\
w_{\text {imp }}(\phi, \theta)= & \left(w_{\text {imp }}\right)_{\max } \times 64(R \sin \phi / a)^{3} \times \\
& (1-R \sin \phi / a)^{3} \cos 2 \theta
\end{aligned}
$$

ただし、 $a=R \sin \theta_{0}$ （款の底面半径）とする。

表 1 解析条件

\begin{tabular}{||c||l||}
\hline 曲率半径 & $R=50 \mathrm{~cm}$ \\
\hline 半 開 角 & $\theta_{0}=10^{\circ}$ \\
\hline ヤング係数 & $E=2.1 \times 10^{6} \mathrm{kgf} / \mathrm{cm}^{2}$ \\
\hline ポアソン比 & $\nu=0.3$ \\
\hline 降伏応力度 & $\sigma_{y}=2400 \mathrm{kgf} / \mathrm{cm}^{2}$ \\
\hline ひずみ硬化係数 & $E_{T}=2.1 \times 10^{4} \mathrm{kgf} / \mathrm{cm}^{2}$ \\
\hline 境界条件 & 周辺完全固定支持 \\
\hline 荷 重 & 自重による軸対称荷重 \\
\hline 初期不整 & 軸対称 inward dimple型 \\
\hline & 非軸対称 cut pie型 \\
\hline
\end{tabular}

表 2 解析パラメータ

\begin{tabular}{||c|c|c|c|c||}
\hline $\bar{\lambda}_{s}$ & $t(\mathrm{~cm})$ & $L_{c r}(\mathrm{~cm})$ & $\lambda$ & $P_{c l}\left(\mathrm{kgf} / \mathrm{cm}^{2}\right)$ \\
\hline 0.4 & 0.59010 & 19.01 & 2.92 & 354.0581 \\
\hline 0.5 & 0.37766 & 15.21 & 3.65 & 145.0222 \\
\hline 0.6 & 0.26227 & 12.67 & 4.38 & 69.9374 \\
\hline 0.7 & 0.19268 & 10.86 & 5.10 & 37.7505 \\
\hline 0.8 & 0.14752 & 9.51 & 5.83 & 22.1286 \\
\hline 0.9 & 0.11656 & 8.45 & 6.56 & 13.8148 \\
\hline 1.0 & 0.09442 & 7.60 & 7.29 & 9.0639 \\
\hline 1.1 & 0.07803 & 6.91 & 8.02 & 6.1908 \\
\hline
\end{tabular}
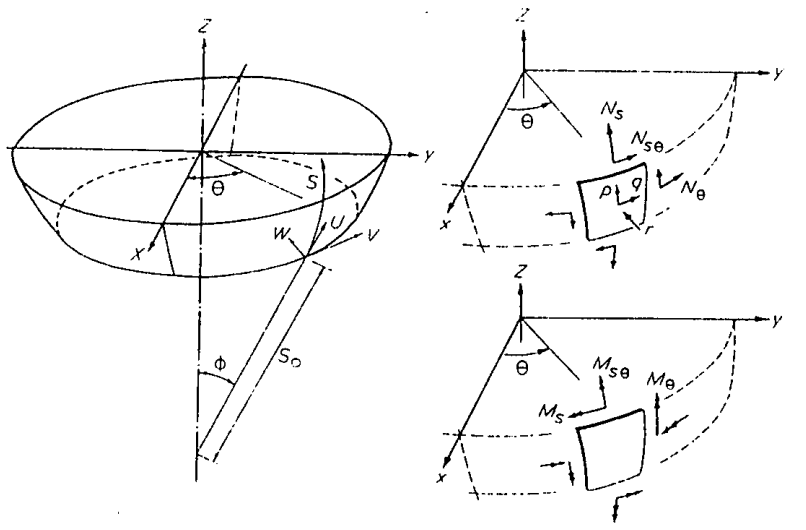

図-1 幾何形状 $\cdot$ 変位・応力の定義

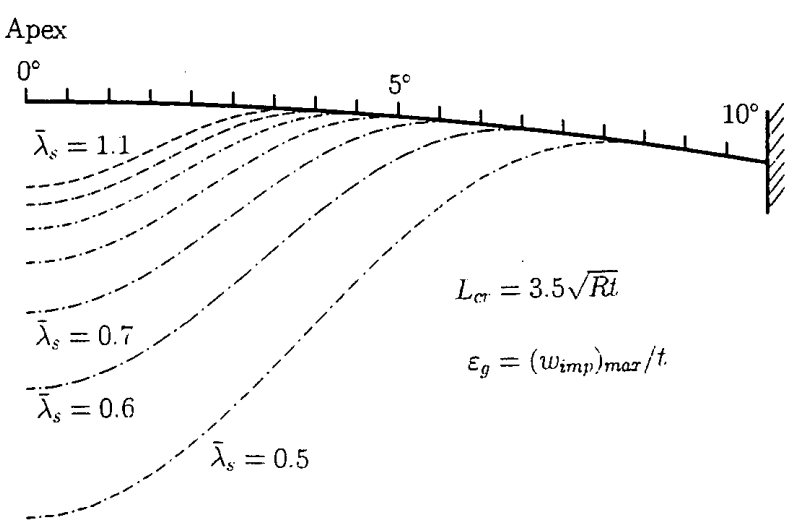

図-2 軸対称・形状初期不整分布

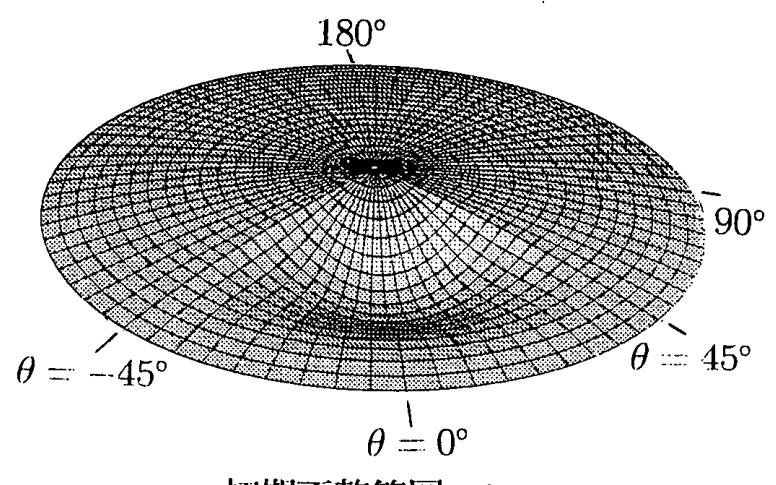

初期不整籁团 $\theta= \pm 45^{\circ}$

図-3 非軸対称・形状初期不整分布 


\section{3. 弹望性座屈解析結果の分析}

完全形状の部分球形殻については 8 ケースの $\bar{\lambda}_{s}=$ $0.4 \sim 1.1$ について、それぞれ弾性座屈解析及び弾塑性 座屈解析を行った。荷重一変位曲線・変位分布・応力及 び相当応力度分布を用いて、基本的な弾塑性座屈性状を 分析する。また、 $\bar{\lambda}_{s}=0.5 \sim 1.1$ については軸対称初期 不整の最大振幅と板厚の比 $\varepsilon_{g}=\left(w_{i m p}\right)_{\max } / t$ をそれぞれ $0.2 、 0.5 、 1.0$ とした場合の計 21 ケースについて 弾塑性座屈解析を行ない、形状初期不整による座屈荷重 の低減係数を調べた。尚、荷重一変位曲線において最初 に荷重が低下する点を弾塑性座屈荷重（塑性崩壊荷重） と定義し、その荷重及びその平均応力度 $(\sigma=P R / 2 t)$ をそれぞれ、 $P_{c r}^{p l}, \sigma_{c r}^{p l}$ と表し、軸対称初期不整のある場合 の弾塑性座屈荷重を $P_{\max }^{p l}$ と表す。非軸対称の初期不整

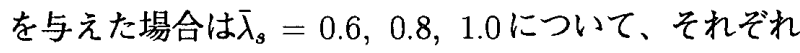
$\varepsilon_{g}=\left(w_{\text {imp }}\right)_{\text {max }} / t=1.0$ を 1ケースずつ、さらに $\bar{\lambda}_{s}=0.8$ については $\varepsilon_{g}=0.2,0.5$ を加えた、計 5 ケースについて 弾塑性座屈解析を行った。非軸対称初期不整のある場合 の弾塑性座屈荷重を $P_{a s m}^{p l}$ と表す。今回の形状初期不整 は $\varepsilon_{g}=1.0$ 以下としているが、より大きな初期不整につ いては今後の課題とする。

3.1 荷重一変位曲線・変位分布及び塑性化の進展

(完全形状の場合)

荷重一变位曲線の性質はほほ $3 \supset 0$ 型 $\left(\bar{\lambda}_{s}=0.4\right.$ 、 $\left.\bar{\lambda}_{s}=0.5 \sim 0.7 、 \bar{\lambda}_{s}=0.8 \sim 1.1\right)$ に分類できる。 $\bar{\lambda}_{s}=0.4$ の場合、弾性では荷重が低下する点が明確に 現れず、弾塑性に打いては殼頂部（Apex）の法線方向 変位 $\left(w_{\text {Apex }} / t\right)$ がほほ 0.2 で荷重が最大となり（塑性 崩壊)、その後荷重はほとんど低下せず変形が進み、壳 頂部上層及び固定支持端の上下層で材料の塑性化が進 行する。 $\bar{\lambda}_{s}=0.5 \sim 0.7$ の場合は弾性・弾塑性とも同 様になだらかな山型の曲線を描き、弾塑性座屈荷重は $w_{\text {Apex }} / t$ がほぼ $0.4 \sim 0.5$ で生じ、殼頂部上層及び固 定支持端の下層で塑性化が生じる。 $\bar{\lambda}_{s}=0.6$ の荷重一変 位曲線及び弾塑性座屈荷重時の塑性化の様子を図 4 に示 す。 $\bar{\lambda}_{s}=0.8 \sim 1.1$ の場合は弾性では起伏の激しい、非 常に複雑な何重一変位曲線を描く。弾塑性においては殻 頂部の変位が一旦減少し、荷重が最大となり、その後荷 重は急激に低下していく。この範囲の $\bar{\lambda}_{s}$ で特徴的なのは 弾望性座屈荷重時の変位分布が殼中間部（頂部と支持部 の中間) で最大（板厚の 0.5 - 0.7 倍）となることで あり、斿が大きくなるほど支持部に近づいていく。壳中 央部の変位を用いた荷重一変位曲線は $\bar{\lambda}_{s}=0.5 \sim 0.7$ の 場合と同様になだらかな山型の曲線となっている。塑性 化は最初に合モーメントの大きな固定支持部で生じ、続 いて殻頂部の下層側及び変位の最も大きい殻中間部上層 側で生じている。 $\bar{\lambda}_{s}=0.8$ の例を図 5 に示す。 3.2 応力分布及び相当応力度分布（完全形状の場合）

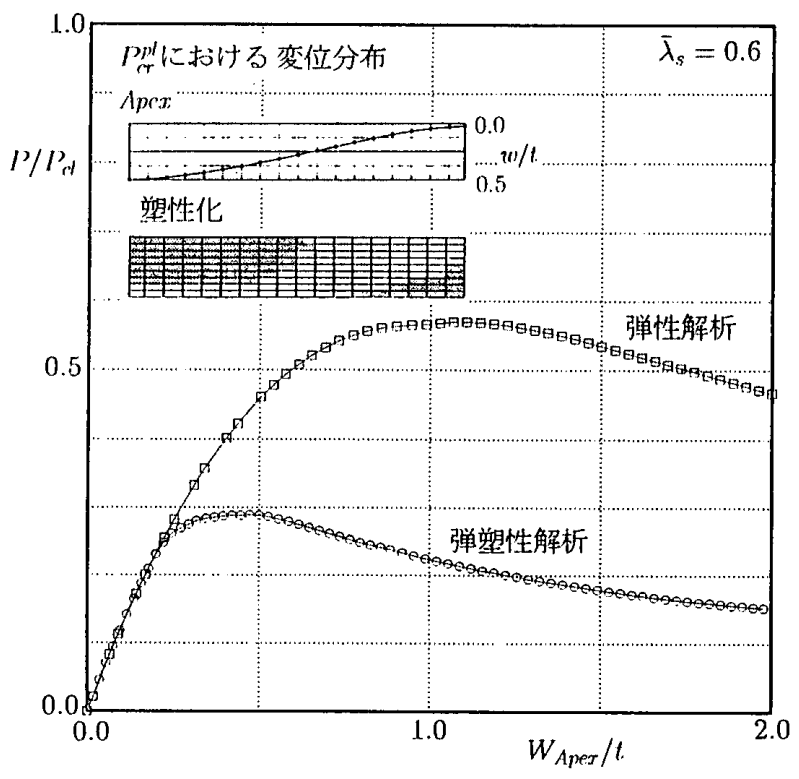

図-4 荷重一変位曲線の例 $\left(\bar{\lambda}_{s}=0.6\right)$

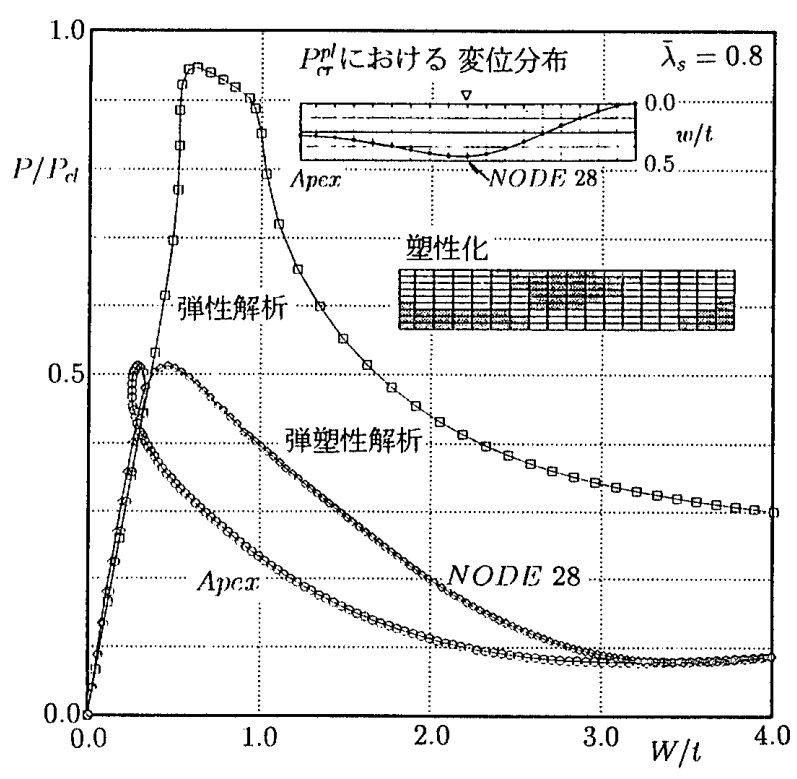

図-5 荷重一変位曲線の例 $\left(\bar{\lambda}_{s}=0.8\right)$

$\bar{\lambda}_{s}=0.6$ 及び $\bar{\lambda}_{s}=0.8$ の場合の弾塑性座屈荷重時の 応力性状をそれぞれ図 6 、図 7 に示す。合応力 $N_{s}, N_{\theta}$ の 傾向はほぼ同じであるが、 $N_{\theta}$ は致が大きい程、膜応力 $P R / 2$ からのずれが少ない。積分点 5 (中央面) の相当 応力度分布をみると、 $\bar{\lambda}_{s}=0.6$ では款頂部から中間部に かけて全般的に大きいのに対して、 $\bar{\lambda}_{s}=0.8$ では変位が 最も大きくなる中間部のみで大きくなっている。合モ一 メントは $\bar{\lambda}_{s}=0.6$ の場合 $M_{\theta}$ が中間部で $M_{s}$ が端部で大き くなっているのに対して、 $\bar{\lambda}_{s}=0.8$ の場合は変位分布に 対応して、 $M_{s}$ が頂部、中間部、端部でそれぞれ大きく なっている。神が大きくなる程、合モーメントの影響が 大きくなり、積分点 1 （上層側）及び9（下層側）の相 当応力度分布が積分点 5 を中心にして互いに鏡像のよう 


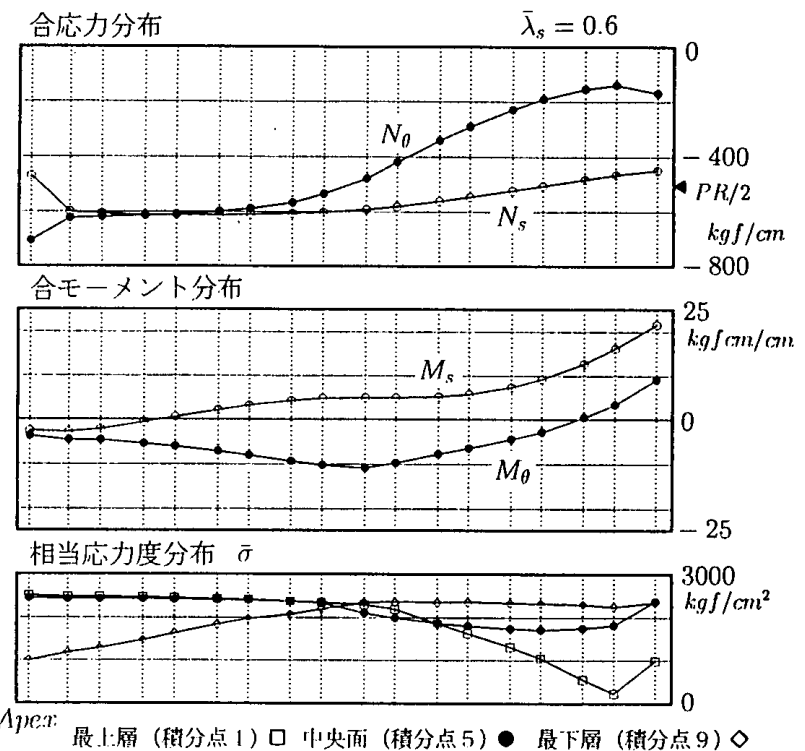

図一6 弾塑性座屈荷重時の応力性状 $\left(\bar{\lambda}_{s}=0.6\right)$
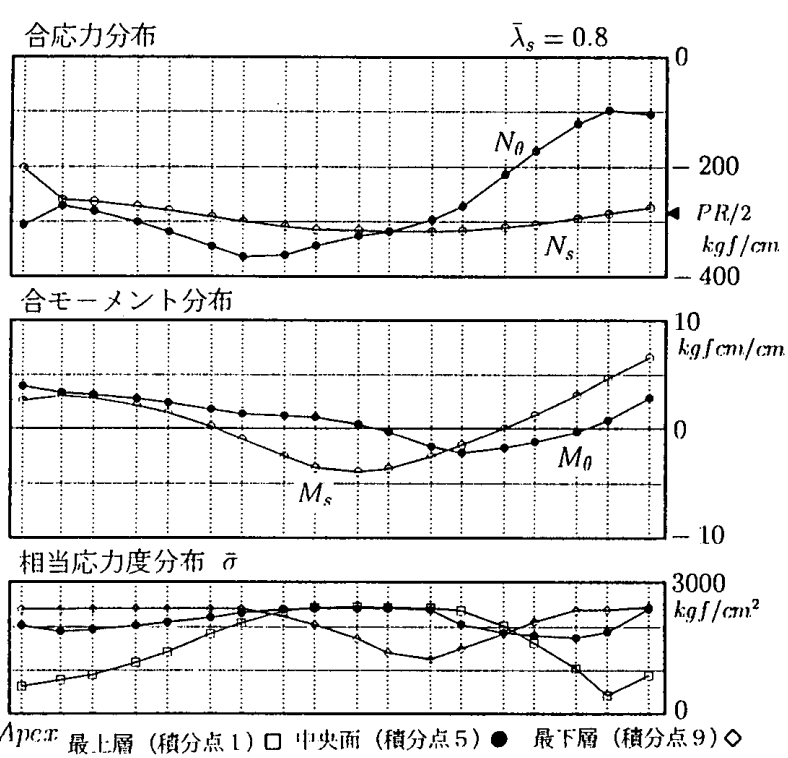

図一 7 弾塑性座屈荷重時の応力性状 $\left(\bar{\lambda}_{s}=0.8\right)$

になっている。いずれにしても合モーメントの影響が小 さい範囲の $\bar{\lambda}_{s}$ では中央面（積分点 5 ）の相当応力度が降 伏応力度に達することで座屈耐力が決まっている。

3.3 軸対称初期不整のある場合

$\bar{\lambda}_{s}=1.0$ について完全形状及び初期不整のある場合 $\varepsilon_{g}=\left(w_{i m p}\right)_{\text {max }} / t=0.2,0.5,1.004$ ケースの荷重一変 位曲線を図 8 に示す。完全形状の場合は殼中間部の変位 が最も大きいが、初期不整がある場合は殻頂部の変形が 大きく、荷重一変位曲線はなだらかな山型となる。特に $\varepsilon_{g}=1.0$ の場合は荷重がほとんど低下せず壳頂部の変 形が進行する。弾塑性座屈荷重時の㪍頁部の変位は弾性 解析の結果 ${ }^{12)}$ に比較すると塑性の影響で小さくなってい る。初期不整の値が大きくなると弾性座屈による低減率

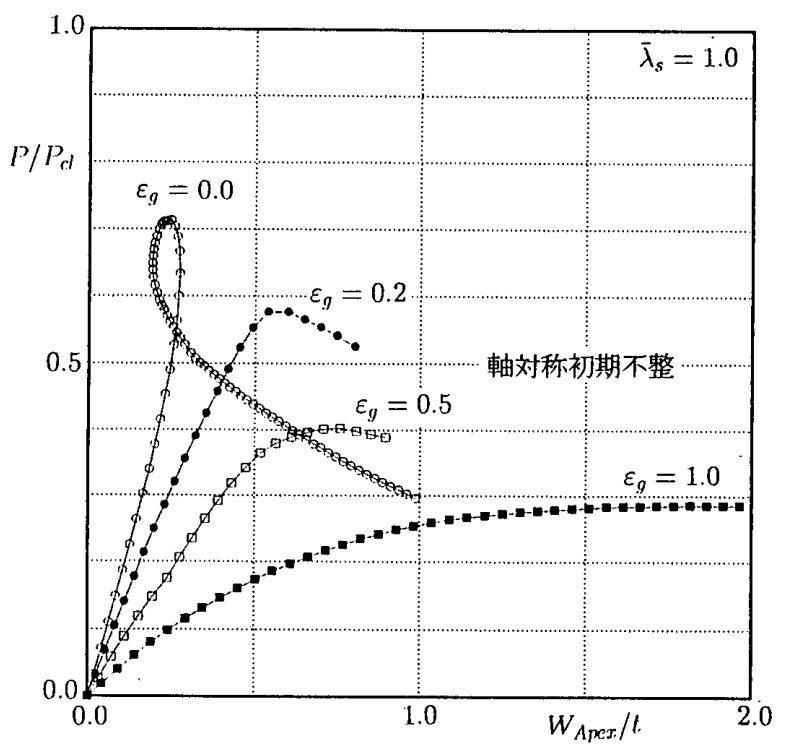

図一8 初期不整がある場合の荷重一変位曲線

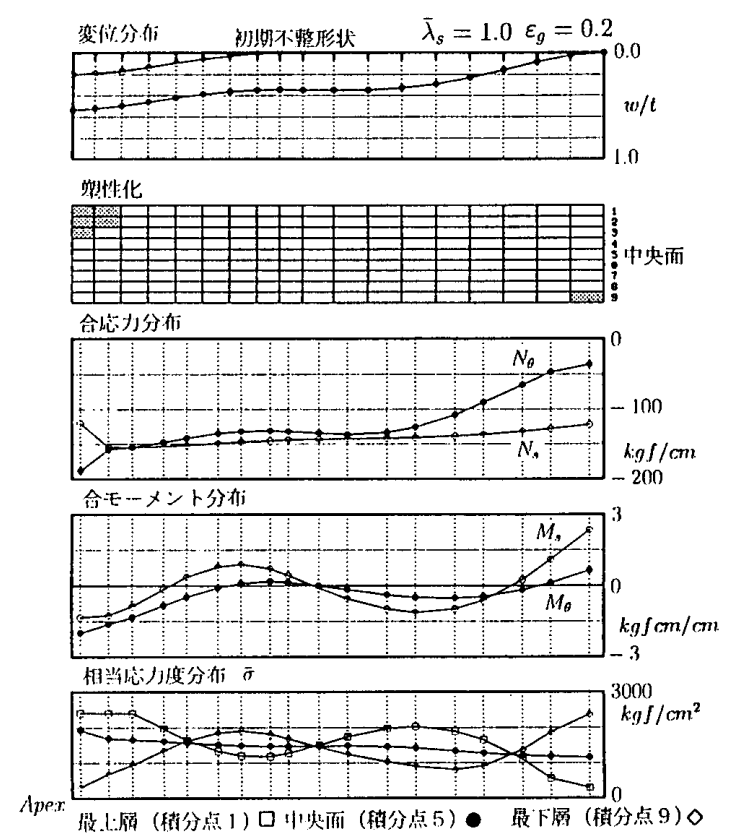

図-9 $\varepsilon_{g}=0.2$ の塑性化及び変位・応力分布

の方がより小さくなり、塑性の影響は小さくなると考え られる。

$\varepsilon_{g}=\left(w_{i m p}\right)_{\max } / t=0.2,1.00$ 場合の弾塑性座屈荷重時 の変位分布·塑性化及び応力分布を図 9 、図 10 に示す。 変位分布は弾性解析による結果と同梯な傾向を示し、殻 頂部の変形が大きい。 $\varepsilon_{g}=0.2$ の場合で特徴的なのは変 位分布から想像されるように合モーメントが数カ所で大 きくなり $M_{s}$ の変化が大きいことであり、その結果、前述 したように相当応力度の分布も変動が大きい。 $\varepsilon_{g}=1.0$ の場合、 $N_{s}$ と $M_{s}$ は初期不整の始まる位置で大きくなり、 $N_{\theta}$ が少し頂部に近い位置で大きくなり、 $M_{\theta}$ は変位分布 と同じように頂部で最大となっている。結果として塑性 


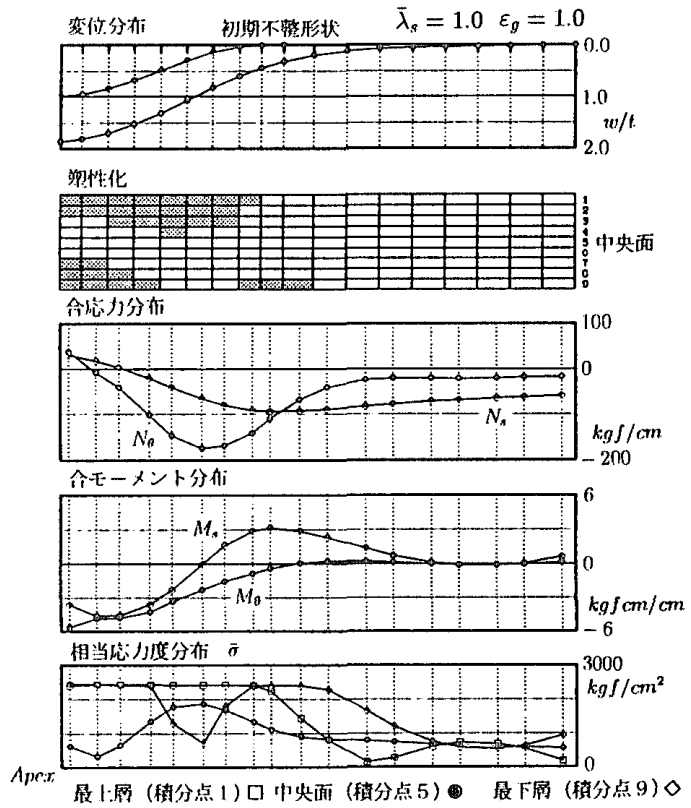

図-10 $\varepsilon_{g}=1.0$ の塑性化及び変位・応力分布

化は初期不整のある位置の上・下層で生じている。これ らは六拘わらず、ほぼ同様な傾向を示している。

今回用いた軸対称初期不整による弾塑性座屈解析結果 としてはKaoによる $\lambda=5,7.5,10.0$ の例7)及びYang \& Liawによる $\lambda=5$ の例9)があるが、いずれも座屈荷重の 結果が示されているだけで塑性化及び変位・応力分布に 関する記述はほとんどない。Yang \& Liawによる座屈荷 重の值は本解析による結果とほほ同様な値となっている が、Kaoの結果は初期不整の值が大きくなると本解析の 結果と比較して座屈荷重がかなり小さくなる。

3.4 非軸対称初期不整のある場合

今回用いた非軸対称初期不整分布はKao \& Perroneに よる弾性座屈 ${ }^{26227)}$ 及びYang \& Liawによる弾塑性座屈 解析泉において用いられたものである。筆者らの調べた 範囲では非軸対称初期不整による弾塑性座屈解析を行っ た例 $(\lambda=6$ のみ) はYang \& Liawによる文献9)のみで ある。 $\bar{\lambda}_{s}=0.6,1.0$ における $\varepsilon_{g}=\left(w_{\text {imp }}\right)_{\text {max }} / t=1.0$ の 弾望性座屈荷重時の变位分布及び塑性化の様子をそれぞ れ図 11 、図 12 に示す。周方向 $\theta=0^{\circ}$ の変位を比較す ると初期不整振幅が最も大きい壳中間部で最大となり、 板厚が薄いほど変位が増幅され、当然ながら変位勾配も 大きくなる。 $\theta=180^{\circ}$ の変位分布をみるとやはり板厚が 薄いほど、初期不整の影響がApexを越えて伝わってい るのがわかる。塑性化の様子はほほ同様に、 $\theta=0^{\circ}$ にお いて変位が最も大きい壳中間部の上・下層及び支持端で、 さらに $\bar{\lambda}_{s}=0.6$ の場合は Apex 付近上層側のほぼ全域で 塑性化している。 $\theta=180^{\circ}$ の結果をみると $\bar{\lambda}_{s}=0.6$ の場 合はApex 付近はほぼ全域で塑性化している。初期不整 の振幅が小さくなると（ $\bar{\lambda}_{s}=0.8$ における $\varepsilon_{g}=0.2,0.5$

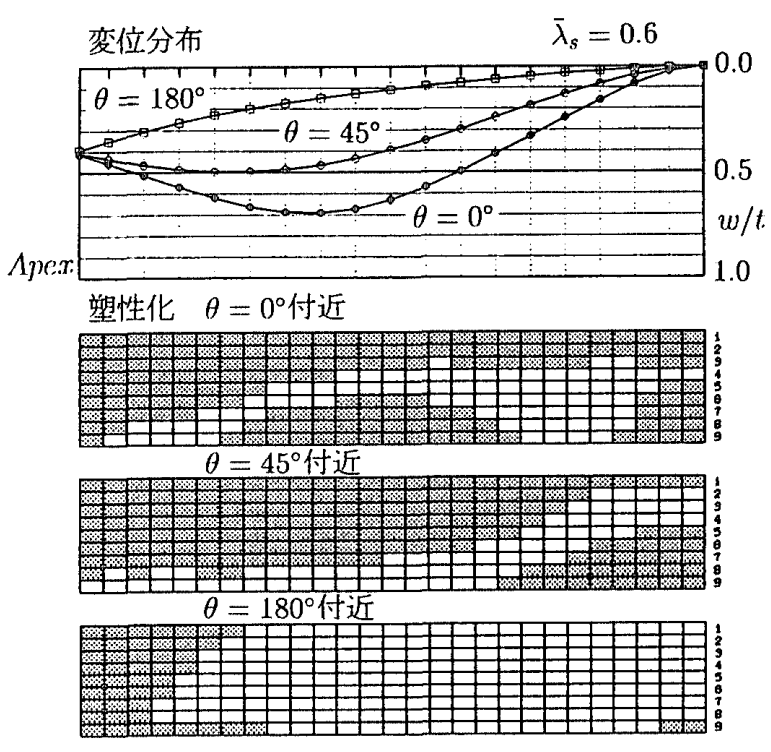

図-11 $\vec{\lambda}_{s}=0.6, \varepsilon_{g}=1.0$ の変位分布及び塑性化

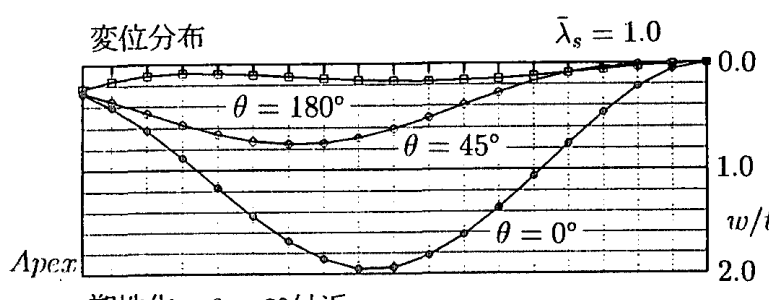

塑性化 $\theta=0^{\circ}$ 付近

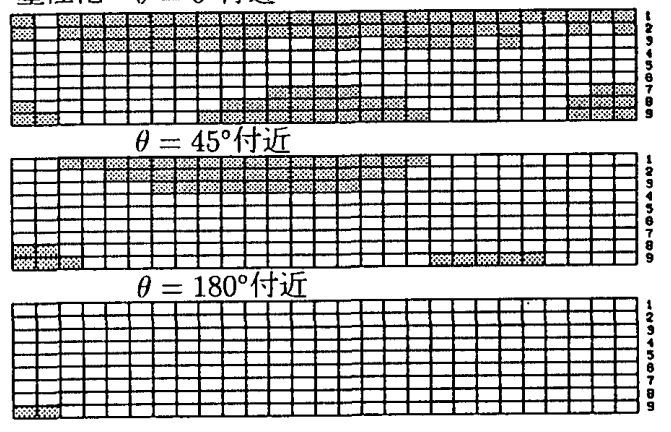

図-12 $\bar{\lambda}_{s}=1.0, \varepsilon_{g}=1.0$ の変位分布及び塑性化

の例)、 $\bar{\lambda}_{s}=1.0$ の結果とほほ同じような傾向を示し、 殻中央部上層及び支持端下層のみで塑性化している。

図13、図14kはそれぞれ、 $\bar{\lambda}_{s}=0.6,0.8$ の場合の 最上層（表層、積分点 1 )、中央面（積分点 5 ）及び最 下層（積分点 9 ）に打ける塑性化の周方向分布（塑性化 した積分点を単に塗り潰したもので塑性域とは違って大 きさに意味はない）を示す。非軸対称cut pie型（片側 $\left.\theta=45^{\circ}\right)$ の初期不整に対して、 $\bar{\lambda}_{s}=0.6$ の場合は初期 不整の範囲を大きく越えて塑性化が広がっており、最下 層では周辺支持部全域か降伏している。ここには示して いないが、 $\bar{\lambda}_{s}=1.00$ 場合は中央面では塑性化はほとん どみられずに、最大耐力に達している。なお、今回は周 方向に $\cos 2 \theta$ )非軸対称初期不整分布のみを対象とした 


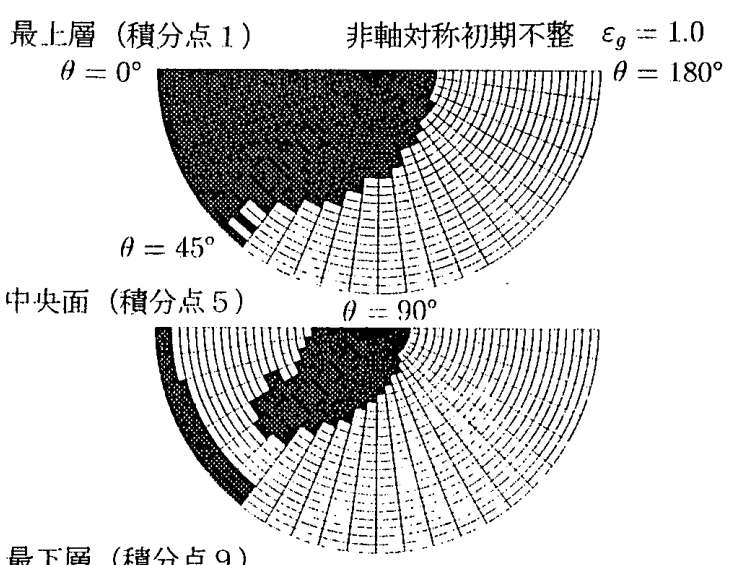

最下層（積分点 9 ）

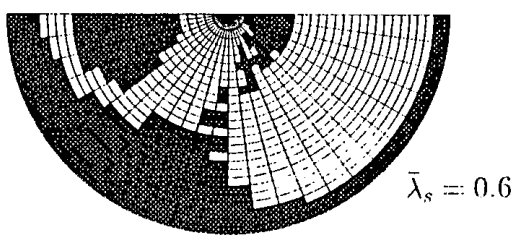

図-13 $\bar{\lambda}_{s}=0.6$ の塑性化の周方向分布

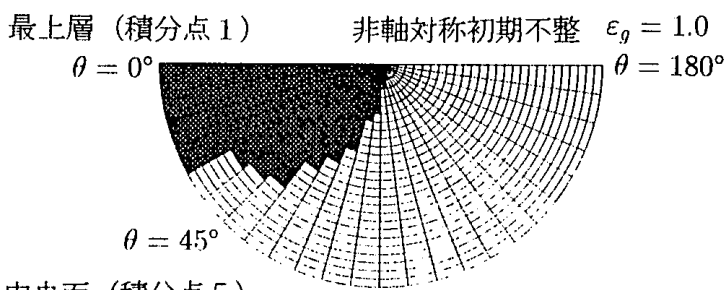

中央面（積分点 5) $\theta=90^{\circ}$

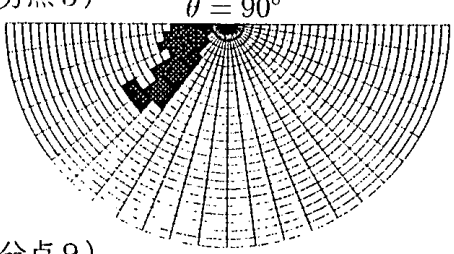

最下層（積分点 9 ）

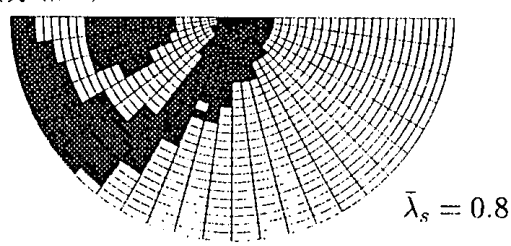

図-14 $\bar{\lambda}_{s}=0.8$ の塑性化の周方向分布

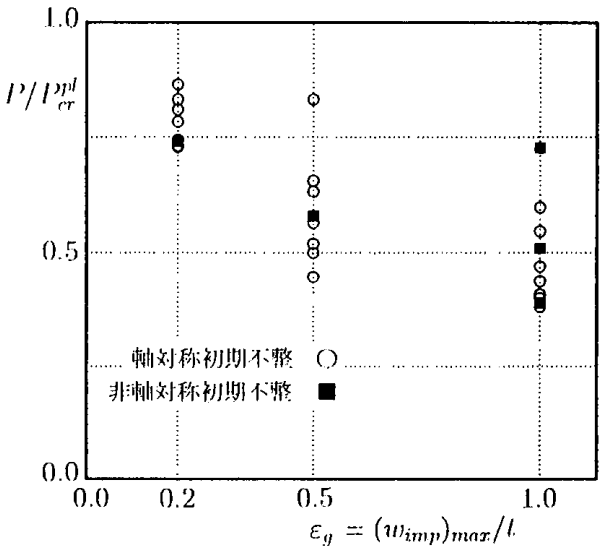

図-15 初期不整敏感性曲線
が、これ以外の不整分布の影響も検討の必要があろう。 3.5 初期不整敏感性

形状初期不整による弾塑性座屈荷重 $P_{\max }^{p l}$ の低減係数 を調べるため、絴軸に $P_{m a x}^{p l} / P_{c r}^{p l}$ 及び $P_{a s m}^{p l} / P_{c r}^{p l}$ 、横軸に $\varepsilon_{g}=\left(w_{i m p}\right)_{\max } / t$ をとった弾塑性の初期不整敏感性曲線 を図 15 に示す。軸対称初期不整の結果を○印、非䡛称 初期不整の結果を印で示している。 $\varepsilon_{g}=0.2,0.5,1.0$ の場合でそれぞれ、最小となる低減係数は $0.72 、 0$. $44 、 0.38$ となっており、初期不整の振幅が大きく なると斿が大きいほど（ $R / t$ が大きいほど）低減係数は 小さくなる。従来、初期不整敏感性曲線は古典座屈荷重 $P_{c l}$ を用いて表されてきたが、弾塑性座屈荷重について は降伏応力度 $\sigma_{y}$ の影響も考虑して、完全形状の弾塑性座 屈荷重 $P_{c r}^{p l}$ からの低減度で表すのが妥当であろう。

\section{4. 座屈耐力曲線上での比較}

4. 1 細長比パラメータ $\bar{\lambda}_{s} に よ る$ 座屈荷重の比較

横軸に $\bar{\lambda}_{s}$ 、縦軸に古典座屈荷重 $P_{c l}$ により無次元化し た座屈荷重 $P / P_{c l}$ をとり各種の座屈荷重の比較を図 16 に示す。図中には既報12)で推定した、合応力のみによる 相当応力度力゙降伏応力度に達する荷重 $P_{y l d 2}^{e l}$ や回転款要素 による数種の座屈荷重をプロットしてある。注 2 に示す ように本解析における弹性座屈解析結果と回転殼要素に よる解析結果はほとんど同じ值となるため、弾性の結果 は既報のものを用いている。合モーメントの影響が小さ い範囲の $\bar{\lambda}_{s}$ では $P_{y l d 2}^{e l}$ は $P_{c r}^{p l}$ と非常に良く合っており、既 報で求めた推定方法が妥当であることがわかる。また、

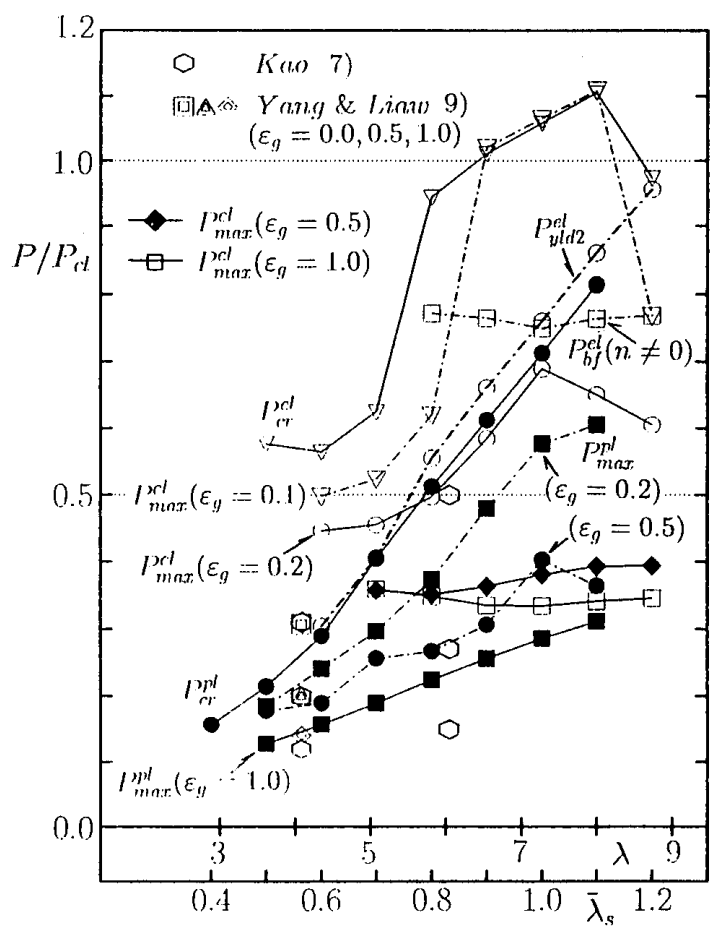

図-16 各種座屈荷重の比較 
$\bar{\lambda}_{s}$ が $1.0 \sim 1.1$ 、幾何形状パラメータ入でほぼ 8 前後 で、弾性の座屈荷重と弾塑性の座屈荷重が互いに交差し ている。

図中には軸対称初期不整による弾塑性座屈解析結果 としてKaoによる $\lambda=5$ の結果7)を示してある。Kaoは 同一の幾何形状パラメータ $\lambda$ 、同一の $\sigma_{y} / E=2 \times 10^{-3}$ となる 2 種類の形状 $(R / t=96.15, R / t=209.69)$ に 対して、初期不整敏感性を含む弾塑性座屈解析を行って いる。その論文中の解析条件から $\bar{\lambda}_{s}$ に換算すると、2種 類の球形殼はそれぞれ、 $\bar{\lambda}_{s}=0.564,0.832$ に相当する。 Kaoが解析で用いた不整を与えた範囲は球形殻全体と思 われ、本解析の条件とは若干異なっているものの、Kao の結果は初期不整の值が大きくなると本解析の結果と比 較してかなり小さくなる。Yang \& Liawによる結果9 本解析による結果とほぼ同様な值となっている。Kaoの 論文中の荷重一変位曲線をみるとピークの值はきちんと 求められておららず、解析手法に問題があると思われる。 いずれにしても、Kaoが指摘したように同一の幾何形状 パラメータ入、同一の $\sigma_{y} / E=2 \times 10^{-3}$ となる、2 種類 の形状 $(R / t=96.15, R / t=209.69)$ をもつ球形款に おいて弾塑性座屈荷重は大きく異なることから、従来か ら行われてきた幾何形状パラメータ $\lambda$ 及び古典座屈荷重 $P_{c l}$ を用いた座屈耐力の表現方法は適当ではない。また、 $\sigma_{y} / E$ の值、いわゆる初期降伏ひずみを変化させた場合 についても検討の必要があろう。

\section{2 既往の実験值及び解析結果との比較}

本解析結果を座屈応力度 $\left(\sigma_{c r}=P_{c r} R / 2 t\right)$ に基づく座
屈曲線として表示し、各種の設計曲線と比較して、そ の特徽を検討する。図 1.7 は放をパラメータとする座 屈耐力曲線である。それぞれ、 $[a]$ 本解析での弹塑性座 屈解析結果、 $[b]$ 代表的な実験結果として、図中の○印 で示される、 $33<R / t<170$ の溶接による鋼製半球 殸の実験結果 ${ }^{11)}$ （D TMB）を用いた。 $[c]$ 設計曲線は、 図中の (1)(2)(3) であり、各々文献28)11)29) から引用し ている。 $[d] \mathrm{Kao}^{7}$ 及びYang \& Liaw" ${ }^{9}$ による弾塑性座屈 解析の結果も挿入してある。本解析の結果と実験值を 比較すると、実駼值は解析結果の $P_{c r}^{p l}$ と $\varepsilon_{g}=1.0$ によ る $P_{\text {max }}^{p l}$ を上下限とした簌囲内に分布している。Galletly

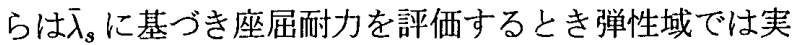
験結果の下限にほぼ合うものの、弾塑性域では既往の 設計曲線及び実験結果に比べて過小に評価寸る傾向に

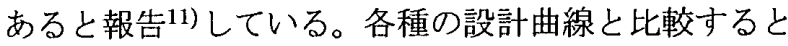
$\varepsilon_{g}=0.5$ の場合、すなわち軸効称初期不整の最大振幅が 板厚の0.5倍の場合においても弾塑性座屈解析の結果は $B S 5500$ や I ASS 設計曲線を下回っており、 $\varepsilon_{g}=1.0$ の場合、すなわち板厚程度の最大振幅をもつ初期不整が ある場合には斌が 0.8 より小さ範囲でDASt $013^{28)}$ を下回っている。ただし、DASt 013 ではinward dimple 型の不整範囲として $4 \sqrt{R t}$ 、その最大振幅で $0.04 \sqrt{R t}$ と いう許容值が設定されており、本解析結果と比較するた め最大振幅を換算すると、 $\bar{\lambda}_{s}=0.6,0.8,1.0$ でそれぞ れ $\varepsilon_{g}=0.552,0.736,0.921$ となり、不整の範囲(本解析 では $\left.L_{c r}=3.5 \sqrt{R t}\right)$ は若干異なるものの、本解析結果 と良く符合している。

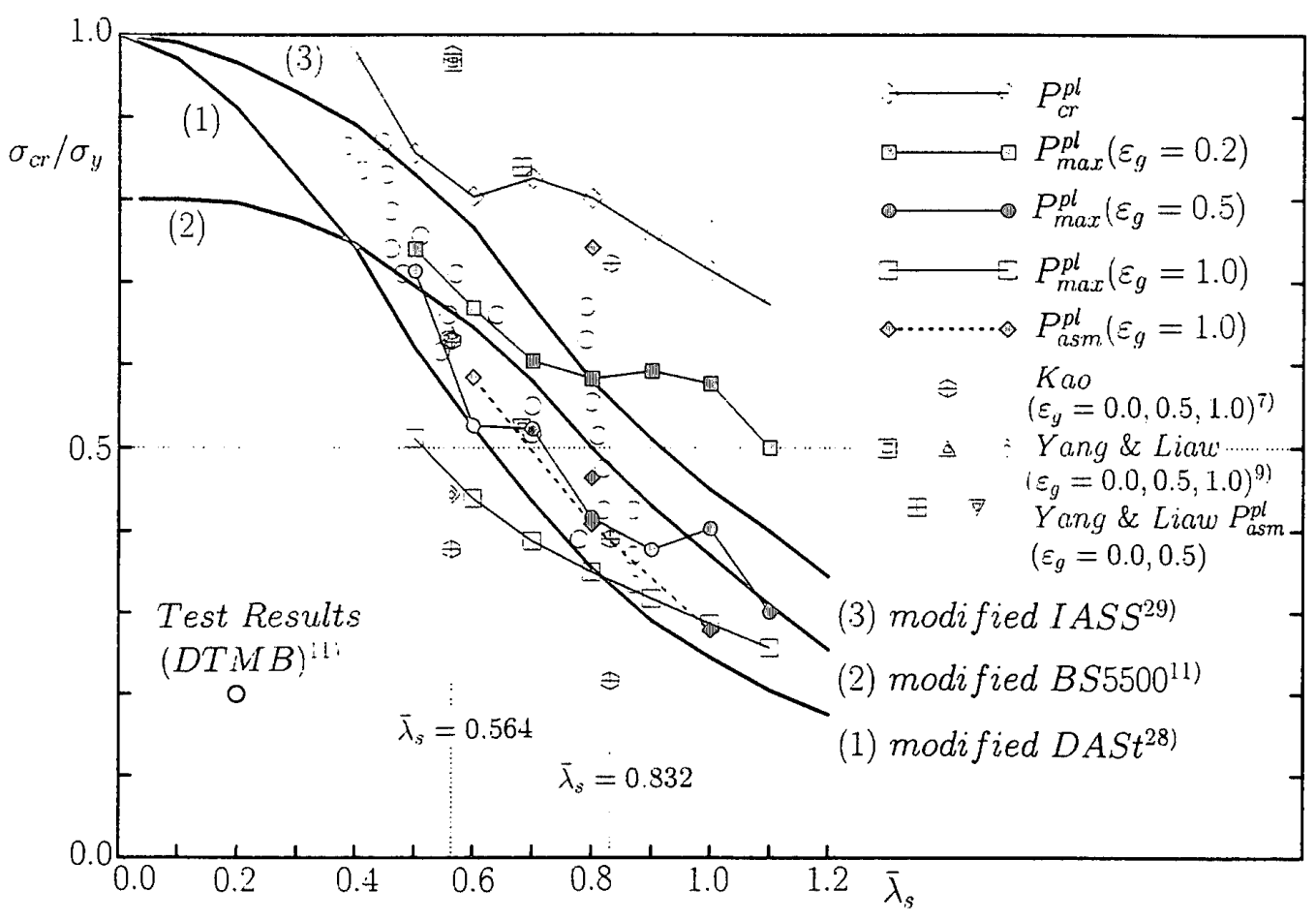

図-17 座屈耐力曲線と設計曲線、実験・解析結果との比較 
本解析結果においては軸対称及び非軸対称初期不整 による弾塑性座屈荷重の低減係数を求めたが、座屈耐 力曲線上でも Yang \& Liaw ${ }^{9}$ の結果と本解析結果はほぼ 合うものの、前述したように $\mathrm{KaO}^{7}$ の結果は初期不整の 振幅が大きくなると座屆耐力がかなり小さい值となって いる。また、本解析で用いた非軸対称初期不整の分布は cut pie型に限られているが、 $\bar{\lambda}_{s}$ が 1.0 より小さい範囲 では軸対称初期不整を与えた場合の座屈耐力のほうがよ り小さくなっている。

\section{5. 結論、将来の研究}

本論では軸対称等分布荷重を受ける周辺固定の部分球 形殼に対して、Ahmad Shell要素による有限要素法を用 い、細長比が 1.1 以下 ( $\lambda$ が約 8 以下) の範囲について 弾塑性座屈解析を実行し、各種の座屈荷重と比較し、座 屈応力度に基づく座屈耐力曲線を求め、既往の研究結果 及び設計曲線と比較・検討した。本研究の結論は以下に 要約できる。

（1）回転款要素を用いた結果とAhmad Shell要素を用 いた結果は非常に良く一致した。これにより、回転款要 素を用いた弾性座屈解析結果と Ahmad Shell要素を用い た弾塑性座屈解析の結果を座屈耐力曲線等で効率よく利 用できる。

(2) 弾塑性座屈解析結果から、 $\bar{\lambda}_{s}$ が 0.7 以下 $(R / t$ が ほぼ２６０）では合モーメントの大きな固定端部分で塑 性化が始まり、続いて合応力の大きな殻中間部分から壳 頂部において塑性化が進行して、少し耐力が上昇し塑性 崩壊に至る。 $\bar{\lambda}_{s}$ が 0.8 以上では固定端部分で塑性化が 始まり、続いて合モーメントの大きな殻中間部の上層側 及び殸頂部の下層側において塑性化が進行して塑性崩壊 に至る。

（3）今回の解析例では殼の中央面（中立面）の塑性化 で座屈耐力が決まるので、弾性解析の $P_{y l d 2}^{e l}$ による弾塑 性座屈荷重の推定は非常に有効である。

（4）軸対称の inward dimple型の形状初期不整による 弾望性座屈荷重の低減係数は $\varepsilon_{g}=\left(w_{i m p}\right)_{\max } / t=0.2$ の 場合でほぼ $0.72 、 \varepsilon_{g}=1.0$ の場合で 0.38 である。 各種の設計曲線と比較すると、かなり小さな値となって いる。

（5）半球壳の実験結果（D T M B）を座屈耐力曲線で 評価すると、今回の弾望性座屈荷重を上限、軸対称初期 不整 $\varepsilon_{g}=1.00$ 座屈荷重を下限とした範囲に分布してい る。

（6）今回想定した非軸対称のcut pie型の形状初期不整 による弾塑性座屈荷重の低減係数は軸対称の場合に比較 してそれほど小さくならない。ただし、 $\bar{\lambda}_{s} か ゙ 1.0$ 以上 になると非軸対称のcut pie型の形状初期不整による低
減係数のほうがより小さくなる。今後は弾塑性を考慮 した非軸詨称分岐座屈解析、さらには非軸対称荷重によ る座屈解析を進め、結果を座屈耐力曲線上で評価・比較 し、弾望性座屈耐力の推定手法に関する研究を行う予定 である。また、材料特性、特に降伏応力度 $\sigma_{y}$ の変化によ る弾塑性座屈荷重の変動についても研究を行う予定であ る。

\section{6. 謝辞}

豊橋技術科学大学助教授・山田聖志博士には計算工学 研究会等を通じて御指導を賜り、また有益な御助言を頂 きました。ここに深く感謝致します。

岐阜工業高等専門学校助教授・武藤至氏には本論文作 成にあたり、非常に有益な御助言を頂きました。ここに 深く感謝致します。

また、本研究における弾塑性座屈解析の検証について は (株) 巴コーポレーション建設技術開発室向山洋一氏 の協力を得ました。ここに記して謝意を表します。

本研究における非軸対称変形を含んだ弾塑性座屈解析 については法政大学計算センターのスーパーコンピュー タVPX210/10を使用しました。記して謝意を表します。

注 1

Ahmad Shell 要素の数值積分については疑似モードやロッキング現 象を避けるため、Heterosis 要素 ${ }^{23)}$ や混合型定式化に基づく退化款 要素30)等をはじめ、さまざまな工夫がなされている。しかし、平 面板の場合と違って、シェルの非線形解析においては变位型の定式 化による選択低減糟分手法 (Heterosis 要素) は最良ではないと考 える15)。沉用プログラムの ADINAにおいても $3 \times 3$ または $2 \times$ 2の糟分を用いて抢り、選択低減皘分は用いられていない。本解析 においては積分点は $3 \times 3$ とした。

注 2

今回用いた弾性及び弾塑性座屈解析プログラムに関しては次の3 種 類の検証解析を行って、その妥当性を検討した。

i) Ahmad Shell 要素による幾何学的非線形解析との比較 ${ }^{31)}$ 中央に集中荷重を受ける偏平な屋根型円筒殻 $(t=6.35 \mathrm{~mm})$ を1/4 対称モデルにより、4 要素· 25 節点（自由度数 12 5)の解析を行った。荷重一変位曲線において、Krätzig らの 結果 ${ }^{31)}$ と非常に良く一致した。

ii）回転款要素による弾性·幾何学的非線形解析との比較 既報12)で用いた回転殻要素（Koiterのひずみ一変位関保式を 用いた Total Lagrangian 型の解析) による結果との比較を行っ た。両者の間にはT.L.及びU.L.の違い、ひずみ一変位関係式 の違いがある。また板厚方向のモデル化についても、一方は合 応力を用いる stress resultant model、他方は数值䅡分を用い る integrating model ${ }^{32}$ )であるが荷重一変位曲線及び合応力． 合モーメントともにきわめて良く一致した。結果の一部を別 表 1 に示す。ひずみが $0.1 \%$ のオーダーになれば構成方程式 に対して座標の変換を考虑する必要があるとされているが19)、 本解析のように変形が板厚の数倍程度になってもひずみはそ れほど大きくなく、弾望性座屈荷重は変形が板厚の 0.5 倍以 下で生じており、T.L.とU.L.の違いは明確には現れないと考 えられる。初期不整のある場合の解析については、回転殻要 素(T.L.)では初期ひずみとして導入する方法、Ahmad Shell 要素(U.L.) では初期形状の変化として導入する方法を用いて いるが、両者の結果は非常に良く一致した。 
iii）汎用プログラムADINAによる弾塑性・幾何学的非楾形解析 との比較

今回の解析モデルによる完全形状 $\bar{\lambda}_{s}=0.6,0.7,0.8$ の ケー スについて、ADINAを用いた結果（Total Lagrangian型、板 厚方向 6 点積分）と比較し、次の別表 2 のような良好な結果 を得た。 $\bar{\lambda}_{s}=0.7$ の場合においては座屈荷重に $8 \%$ ほぼ違い があるが、荷重一変位曲線・塑性化の進展等については定性 的にほぼ同様な結果が得られた。

別表 1 弹性・幾何学的非線形解析

\begin{tabular}{||c|c|c|c||}
\hline$\lambda_{s}$ & $\begin{array}{c}P_{c r}^{e l}\left(\mathrm{kgf} / \mathrm{cm}^{2}\right)(A) \\
\text { Ahmad Shell 要菜 }\end{array}$ & $\begin{array}{c}P_{\mathrm{cr}}^{e l}\left(\mathrm{kgf} / \mathrm{cm}^{2}\right)(B) \\
\text { 回転款要素 }\end{array}$ & $(A / B)$ \\
\hline 0.6 & 39.859 & 39.448 & 1.010 \\
\hline 0.7 & 23.618 & 23.595 & 1.001 \\
\hline 0.8 & 20.962 & 20.912 & 1.002 \\
\hline 0.9 & 14.007 & 13.967 & 1.003 \\
\hline
\end{tabular}

別表 2 弾塑性・幾何学的非線形解析

\begin{tabular}{||c|c|c|c||}
\hline $\bar{\lambda}_{s}$ & $\begin{array}{c}P_{c r}^{p l}\left(\mathrm{kgf} / \mathrm{cm}^{2}\right)(A) \\
\text { ADINA }\end{array}$ & $\begin{array}{c}P_{c r}^{p l}\left(\mathrm{kgf} / \mathrm{cm}^{2}\right)(B) \\
\text { 本解析 }\end{array}$ & $(A / B)$ \\
\hline 0.6 & 19.705 & 20.218 & 0.975 \\
\hline 0.7 & 13.959 & 15.262 & 0.915 \\
\hline 0.8 & 11.316 & 11.337 & 0.998 \\
\hline
\end{tabular}

\section{注 3}

非軸対称変形を含んだ解析としては非軸対称分岐座屈解析があげ られる。Galletly ${ }^{10)}$ は汎用プログラムのBOSOR及びF A S ORを用いて $\lambda=7.5,10.0$ の弾塑性・非軸対称分岐座屈荷重を求 めており、それぞれ $P / P_{\mathrm{cl}}=0.54 \sim 0.55 、 P / P_{\mathrm{cl}}=0.76$ の結果 を得ている。 $\lambda=7.5 ， 10.0$ を解析条件より換算するとそれぞれ、 $\bar{\lambda}_{s}=0.59,0.79$ の場合に相当する。本解析における初期不整を有 する結果と比較するとかなり高い値となっている。非軸対称分岐座 屈解析については改めて別報にて報告する予定である。

\section{参考文献}

1) Kollár L. and Dulácska E. : Buckling of Shells for Engineers, John Wiley \& Sons, 1984.

2) Bushnell, D. : Computerized buckling analysis of shells, Martinus Nijhoff Publishers, Dordrecht, 1985.

3) Bornscheuer, F.W.. : To the Problem of Buckling Safety of Shells in the Plastic Range, Proc. of a State-of-the-Art Colloquium Universität Stuttgart, pp.601-619, 1982.

4) ECCS : The Buckling of Shells, European Recommendations for Steel Construction, Brussels, Publication 29, 1983.

5) BS5500 : Specification for Unfired Fusion Welded Pressure Vessels, British Standards Institution, London, 1984

6）安藤良夫、飯田国広、川井忠彦、矢川元基、菊地文雄 : 有限 要素法による軸対称かくの弾塑性大たわみ解析、日本機械学 会論文集（第 1 部）、第 37 巻 303 号、pp.609-619, 197 1 年 11 月

7) Kao, R. : Large Deformation Elastic-Plastic Buckling of Sperical Caps with Initial Imperfections, Computers \& Structures, Vol.11, pp.609-619, 1980.

8) Bushnell, D.: Plastic Buckling of Various Shells, J. of Pressure Vessels, Vol.104, ASME, pp.51-72, 1984.

9) Yang, T.Y., Liaw, D.G. : Elastic-plastic dynamic buckling of thin-shell finite elements with asymmetric imperfections, J. American Inst. of Aeronautical and Astronautics, Vol.26, No.4, pp.479-486, 1988.

10) Blachut, J., Galletly, G.D. : Buckling Strength of Imperfect Spherical Caps - Some Remarks, AIAA Journal Technical notes, Vol.28, No.7, pp.1317-1319, 1990.
11) Galletly, G.D., Blachut, J. : Buckling design of imperfect welded hemispherical shells subjected to external pressure, Proc. Instn. Mech. Engrs. 205(C), pp.175-188, 1991.

12）千葉義尚、加藤史郎、武藤至 : 部分球形殻の弾性座屈荷重の 表現方法に関する比較・考察、日本建築学会構造系論文集第 458 号、pp.69-78、1994年4月.

13) Chiba, Y., Kato, S. and Mutoh, I. : Various Expressions for Elastic Buckling Loads of Spherical Caps, Proc. of the SEIKEN-IASS Symposium, pp.129-136, 1993.

14) Bathe, K.J. : Finite Element Procedures in Engineering Mechanics, Prentice-Hall, Engelwood Cliffs, New Jersey, 1982.

15) Chang, T.Y. and Sawamiphakdi, K. : Large Deformation Analysis of Laminated Shells by Finite Element Method, Computers \& Structures, Vol.13, pp.331-340, 1981.

16) Chang, T.Y. and Sawamiphakdi, K. : Large Deflection and Post-buckling Analysis of Shell Structures, Journal of Computer Methods in Applied Mechanics and Engineering Vol.32, pp.311-326, 1982

17）都井裕 : 構造要素クラッシュ挙動のモデル化とシミュレーショ ン, 生産研究第 38 巻 8 号, pp.23-30,1986 年8月。

18) Washizu, K. : Variational Methods in Elasticity and Plasticity, 2nd ed., Pergamon Press, 1975.

19）鹪津久一郎他共編：有限要素法ハンドブックII応用編, 培風 館, 1983 年.

20）日本塑性加工学会編：非線形有限要素法、コロナ社、199 4 年.

21）久田俊明：非線形有限要素法のためのテンソル解析の基礎、 丸善、1992 年

22）富田佳宏：数值弹塑性力学、養賢堂、1990年

23) Owen, D.R.J. and Hinton, E: Finite Elements in Plasticity -Theory and Practice-, Pineridge Press Limited, Swansea, 1980 .

24) Ramm, E. : Strategies for Tracing the Nonlinear Response Near Limit Points : Nonlinear Finite Element Analysis in Structural Mechanics, Proc. Europe-U.S. Workshop RuhrUniversität Bochum, Springer-Verlag, pp.63-89, 1981.

25) Cook, R.D., Maslkus, D.S. andesha, M.E. : Concepts and Applications of Finite Element Analysis, 3rd ed., John Wiley \& Sons, 1989.

26) Kao, R., Perrone, N. : Asymmetric Buckling of Sperical Caps With Asymmetrical Imperfections, Journal of Applied Mechanics, Vol.38, pp.172-178, 1971.

27) Kao, R. : A Note on Buckling of Sperical Caps With Initial Asymmetrical Imperfections, Journal of Applied Mechanics, Vol.39, pp.842-844, 1972.

28) Bornscheuer, F.W. : Schalenbeulen : von der DAStRichtline 013 zu DIN 18800 Teil 4, Bautechnik 65, H.10, S.325-331, 1988.

29) Medwadowski, S.J.(Chair.) : Recommendations for Reinforced Concrete Shells and Folded Plates, IASS, Madrid, 1979. (川口 衛訳：I A S S 鉄筋コンクリートシェル及び折板 構造指針、季刊力ラムN o. 78 , pp.79-96, 1980 .)

30）山田贵博、和田章 : Hu-Washizu の原理に基づく混合型 9 節点 殼要素、日本建筮学会学術講演梗概集 (関東)、pp.1305-1306、 昭和 63 年 10 月.

31) Krätzig, W.B., Basar, Y. and Wittek, U.: Nonlinear Behaviour and Elastic Stability of Shells - Theoretical Concepts - Numerical Computations - Results, Proc. of a State-of-theArt Colloquium Universität Stuttgart, pp.19-56, 1982.

32) Ramm, E. and Stegmüller, H. : The Displacement Finite Element Method in Nonlinear Buckling Analysis of Shells, ibid., pp.201-235.

（1995年 7 月 6 日原稿受理，1995年 9 月13日採用決定） 